\title{
Rethinking Balinese Dance
}

Special edition on Indonesian performing arts

Indonesia and the Malay World

35: 101

March 2007

CMark Hobart August 2006 
How should we set about understanding dance in Bali and its relevance to the study of Indonesia and the Malay world? Is it one of the great contributions to Malay civilization to be appreciated and studied alongside classical Indian and Japanese performance? Or, is it inextricable from religion and best considered as ritual? As a spectacle watched by hundreds of thousands of tourists a year, is it instead a culture industry? Or is it all these woven together to produce a hybrid mass pilgrimage? And what can the critical study of Balinese dance contribute to a broader understanding of cross-cultural performance?

\section{Some problems with Balinese Dance}

That which distinguishes the choreographic art of Bali is traditional character. The dances, the dialogues, the choruses, have been repeated in exactly the same way for centuries. A dancer would never dare modify them, and I'm not referring to a body position or a step but not even the movement of one finger. And yet these ritual dances retain a living beauty and an extraordinary youthfulness. When watching them, one has the impression of seeing the bas-reliefs of ancient Khmer monuments come to life: what appears before us is the supernatural world of the celestial nymphs that covers the walls of the temples of Java (Prunières 1931).

There is no word in the Bali language for "art" or "artist". In Bali, art is not a thing but a profound sentiment, indefinable and indefinite... Dancing is a ritual, dance poetry, movement created by the soul, possessed and conquered (Fels 1931: 995.). ${ }^{1}$

The serious study of dance in Bali encounters the problem of how to extricate it from more than a century of European - and now Balinese and Indonesian fantasy. Granted the singular place Balinese dance has held in the world of nonWestern performance, remarkably there has been virtually no critical analysis of received accounts, of its history and social background, or of the relationship between Balinese and outsiders' understandings. Despite reviews of the pervasive Orientalism to which Bali has been subject (Boon 1977; Vickers 1989; Picard 1996), as the quotations above suggest, not much has changed.

Awash as we are with reiterated truths, what do we actually know about theatre and dance? As Bali was only finally conquered by the Dutch between 1906-10, what kind of knowledge we have of the pre-colonial period becomes salient. And what impact did the demise of the ancien régime and the advent of cultural tourism have on performance? Are we seriously to accept, as do most commentators, the colonial dogma that Balinese culture was effectively untouched by conquest? What were the circumstances under which the accounts were written? For what purposes? How were the authors themselves positioned and implicated? For what readership were they designed? How have Balinese imagined and represented their own theatrical practices at different times? Indeed, what attitudes do Balinese take to the documentation, classification, understanding and analysis of their theatre, dance and

\footnotetext{
${ }^{1}$ Both Prunières and Fels are cited in Savarese 2001 as commentaries on the Paris Colonial Exhibition of 1931. My thanks to Richard Fox, Peter Worsley and Adrian Vickers for their comments on the draft of this article and to the two anonymous referees.
} 
music as cultural products? Are such issues as central, say, as concern with the quality of performance, or with addressing the demands of changing circumstances, audiences' tastes and new media like radio, television and VCDs? Far from knowing all there is to know about Balinese dance, we are still struggling to work out what questions we might intelligently ask.

A further problem is that, anecdotal stories apart, the actualities of performances in pre-colonial Bali remain uncertain. The result is an open season for retrojecting onto an imagined past whatever has suited the needs of particular works or authors. Unfortunately, accounts from the colonial period and later are not problem-free either. De Zoete and Spies's pioneering Dance and drama in Bali set itself the task of introducing the various main genres of Balinese theatre to a readership with no background to Indonesia. However Spies was a complex and ambiguous figure in the romanticisation of the island and in helping to forge the hegemonic account that subsequent works replicate - largely uncritically (Vickers 1998: 105-24; Hitchcock and Norris 1995). Later works, like Moerdowo's Reflections on Balinese traditional and modern arts, or Bandem and deBoer's Balinese dance in transition, had different aims, respectively to provide an Indonesian account of Balinese dance, and to fill in the gaps and describe what had happened to theatre and dance since de Zoete and Spies. More recently Dibia and Ballinger's Balinese dance, drama and music broke new ground in including how Balinese, not just Europeans and Americans, approach their performing arts. However, as the sub-title suggests, it is an introductory guide, rather than a critical account.

A comprehensive study of Balinese dance is impossible. Instead a critical review of what we presume we know is long overdue. Sceptical as my argument is, my aim is positive. Only if we question received truths will it be possible to start the task of reconsidering theatre and dance in Bali seriously; and to argue urgently for the admission of Balinese performers and audiences to this discussion. The idea that dance was ancient, widespread, popular and demotic and the defining feature of Balinese culture is, I submit, largely a western fantasy driven by its own imperatives. Rather, there was, in most European senses of the term, almost no dance in Bali until after conquest and the arrival of tourism in the 1920-30s. European colonialists and tourists expected the natives to dance. And the Balinese obliged their conquerors brilliantly - inter alia by inventing Kebyar (see below). Balinese dance began life in effect as an international phenomenon, the outcome of a double encounter of Europeans and Balinese - notably through tourism and international exhibitions.

There is a problem however in rethinking the pre-colonial history of Balinese dance, namely the paucity of reliable sources. Is my account not therefore itself speculative? However the onus is on proponents of an ancient pedigree to substantiate their claim. It would be strange method to argue that the absence of evidence for dance constitutes evidence for the presence of dance. Given how little we know about the history of Balinese theatre and dance, therefore a judicious summing up of the state of knowledge would be a somewhat empty exercise. With so much conjecture and so little refutation, what we require at this stage is sustained 
critical questioning of - indeed perhaps a revolution in - our thinking, to encourage which my style is intentionally combative. ${ }^{2}$

What exactly am I arguing? First there is a problem with method. Pre-colonial textual references to performances are not of themselves necessarily informative, because what the terms themselves denote are subject to continued change. Balinese have continually reworked dance in the twentieth century. We have no grounds to think they did not beforehand. For the record, I am not claiming that there were no performances in pre-colonial Bali that we might loosely label 'theatre' or 'dance'. It would have been remarkable in the world of South and South East Asia had there not. Certainly courts were notionally patrons of the arts. However, establishing what actually went on behind idealised or hagiographic representations of courtly life is exceptionally difficult. But quite what is at issue? Part is a semantic problem. Part is ignorance of Balinese categories. It is necessary to distinguish dance from theatre because the creation of the phenomenon of 'Balinese dance' involved the determined and meticulous stripping out of singing, dialogue, narrative, philosophy, and historical and cultural referents, which marked theatre at least as scholars knew it from the 1930s on. 'Dance', as it came to be, requires a separate label for a quite distinct phenomenon. Because, through the establishment of Western-style conservatories, it came to be hegemonic, I focus here on the elaboration of the idea of dance as opposed to theatre, which has remained largely unregulated, feral and popular among Balinese themselves.

What is it anyway about dance in Bali that is supposed to be so special? If princely courts entertained themselves and visitors with occasional performances, especially at grand ceremonies, how did Bali differ from most other stratified Asian societies? Were they not to have held dances that would have been interesting. What is supposed to make Bali distinct however is that dance was popular. But was it popular in the sense of being widespread, frequent, accessible, public and engaging a substantial proportion of the populace? Or did it emerge from and exist for ordinary people? I doubt either was the case. Another argument for the special status of dance in Bali is that it constituted a privileged figure through which to understand Balinese culture more broadly. ${ }^{3}$ What, however, singles out dance as against a whole host of other cultural practices?

\footnotetext{
${ }^{2}$ Adumbrating the main problems precludes a detailed discussion of suggestions for future work, a task in which Balinese should be key participants. However, it would inappropriate not to indicate where inquiry might head. As we may well never retrieve more than tantalizing glimpses from the pre-colonial sources without adequate context for proper historical analysis, two obvious themes for future research suggest themselves. The first continues work by recent authors (e.g. Picard 1996; Vickers 1989), namely the critical analysis of how Europeans and Americans have imagined Bali and its significance both for their own societies and for Balinese. The second is a cultural analysis of how Balinese themselves have thought about, approached and used theatre and dance. A parallel analysis of Balinese understandings of their own history has proven revelatory (Wiener 1995).

${ }^{3}$ Such synecdoche (using part to typify the whole), as Clifford has argued (1988), is an established, but problematic, method in social and cultural anthropology. Bali is a notable casualty of this method, where a single image like theatre promises to reveal the complexities of Balinese culture as a whole.
} 
Maybe I am barking up the wrong tree. Perhaps it is its religious or ritual nature that singles out Balinese dance? By the 1930s, we have accounts of plays such as Calonarang $^{4}$ and Basur being performed when Balinese felt threatened by disease or witchcraft, and Topèng Pajegan ${ }^{5}$ as part of temple ceremonies (piodalan), or dances like Réjang, Baris Gedé and Mèndèt. We need to be cautious. For example, Réjang Déwa, which 'has now become the standard in many villages throughout the island' (Dibia and Ballinger 2004: 56) - and which many villagers swear is primordial was choreographed in 1988 by Swasti Wijaya Bandem from STSI. ${ }^{6}$ In North Gianyar, where I worked from 1970-72, Baris Gedé consisted simply in ordering the nearest youths to hand: 'Oi. Grab those spears. Now walk up and down three times'. Mèndèt comprised elderly women desultorily offering holy water and incense to shrines, while caricaturing dance movements delightfully replete with gestures most Europeans would consider obscene. Balinese indeed now often say that religion and performance are inextricable. However this articulation is modern and relates to the need to make Balinese religion acceptable to the Indonesian state. ${ }^{7}$ Then again the relationship between what westerners usually call religion and what Balinese call agama is a twisted tale (see Fox 2002). What constitutes dance, what religion, when and according to whom? Designating dance in Bali as religious raises new problems and in the end explains little. ${ }^{8}$

\section{Digression - history as projected prejudice}

As my argument is condensed, let me review briefly the kinds of issue at stake. After all, can recourse to history not clear up many of the problems of the provenance of dance? For example, the doyen of Indonesian dance studies, Soedarsono, provides a long and magnificent history for Balinese dance, stretching way back to the pre-Hindu-Buddhist epoch (up till 400 A.D.) when dance was magical and sacred in character as distinct from the subsequent feudal period when the modern forms gradually emerged (1972: 125-32). Satisfying as this might seem, Soedarsono's account raises some of the difficulties involved in invoking history. He offered no evidence for his dates. And his account was driven by the demands of the project of a nationalist history, which required a long and distinguished pedigree

\footnotetext{
${ }^{4}$ Accounts of each genre can be found in Dibia and Ballinger 2004.

${ }^{5}$ Interestingly Moerdowo dates Topèng Pajegan to 1919, 1977: 68.

${ }^{6}$ The role of conservatories, especially STSI (The Indonesian Academy of Arts, later ISI, the Institute of Arts) Denpasar, in codifying, standardizing, promoting and determining what constituted dance is crucial.

${ }^{7}$ Visitors are often given a neat division of dance into Wali (offerings, 'sacred' dances performed in temples), Bebali (Semi-ceremonial dances, which supplement ritual) and Balih-Balihan (dance for entertainment). This classification was invented by a committee of Balinese intellectuals in 1971 in response to perceived threats to Balinese culture from tourism and even its authors now admit it does not work.

${ }^{8}$ Anthropologists use ritual as a residual category for whatever appears to defy rational or material explanation and is therefore deemed 'symbolic' (Hobart 2000: 239-249). Here, calling dance 'ritual' or 'symbolic' merely defers analysis. If anything, it is the European obsession with projecting fantasies onto Bali that is 'ritual' and requires study.
} 
for dance. ${ }^{9}$ An initial difficulty in determining what was the case is that the various histories of Balinese dance are driven by diverse, often incompatible agendas.

The complex and interesting problems in interpreting Bali's past are, however, revealed in the pitfalls faced when trying to trace the ancestry of masked dance, Topèng, in two authoritative works on Balinese dance (Moedowo 1977; Bandem and deBoer 1995 [1 ${ }^{\text {st }}$. edition 1981]). We have to read the two sources together to obtain a coherent account. Moerdowo starts by noting that 'the Topeng-mask dance was already well known in the literature of the Negarakrtagama' (a Javanese text about Majapahit in 13-14 ${ }^{\text {th }}$. centuries, (1977: 67) and, according to a family history, the Babad Blahbatuh, were first brought as war booty from Blambangan in East Java in the late sixteenth century. The next reference is nearly a century later when

sometime between 1665 and 1686, during the reign of Dalem Batu Renggong's grandson, Dalem Dimade, Patih I Gusti Pering Jelantik composed a dance-drama. The captured masks were brought out and used for the first time in the premiere performance, called Topeng Pajegan. (Bandem and deBoer 1995: 47). ${ }^{10}$

Then

there was a gap, in which the history of the Topeng could not be traced. [Until] in 1919 in Blahbatuh appears the Topeng Pajegan... The next development of the Topeng dance drama was called the Panca Topeng, played by five persons, who wear different masks' (Moerdowo 1977: 68-69, my parentheses).

However, what 14th century Javanese masked dance looked like and what relationship it bears to 20th century Balinese masked dance is anyone's guess. On these accounts, Topèng in Bali in something like its present form post-dates Dutch colonization.

It may not come as a surprise then to learn that the history of Bali's most famous dance, Lègong, is - literally - fabulous. Author after author replicate dynastic claims of royal genesis as matter of fact. The story usually goes something like this:

a scion of the southern Gianyar court in Sukawati, Cokorda Madé Karna (reputedly 1775-1825), moved to the nearby village of Kètèwèl where, while practising yoga, he dreamed of heavenly nymphs dancing. Unable to find any girls beautiful enough to perform the dance, Cokorda Madé ordered two exquisite masks to be made, which is attributed as the origin of the ritual dance, Sanghyang Lègong.

\footnotetext{
${ }^{9}$ For obvious reasons the idea that even the arts - and so culture-as-civilisation - were a product of a colonial encounter was unappealing to nationalist sentiments.

${ }^{10}$ According to Bandem and deBoer, after being shown to the king of Gèlgèl, the masks were brought back to Blahbatuh, where they 'were then stored in the palace treasury, where they lay unused for a century' (1995: 47). However, according to Moerdowo, the masks were stolen from the kingdom of Gèlgèl by the ancestor of Blahbatuh who fled for his life with them (1977: 67-68). Delightfully, interpretations are further complicated by the key figures all having the title I Gusti Ngurah Jelantik, which allows history to be collapsed and continuities imagined. Moerdowo, himself Javanese, established the trend for using Javanese sources to explain Balinese dance.
} 
However, when Moerdowo tried to confirm this story with the priest of the temple where the masks are kept, he was told 'these masks were in existence before the time of Majapahit, which is at least 400 years ago and it is believed, that these masks come from East-Java' (1977: 91). ${ }^{11}$

The search for the original form of Lègong becomes more tangled still, because several versions were around in the 1920s and 1930s when Europeans became fascinated by the form. These include Sanghyang Lègong which, being performed on religious occasions, is ipso facto assumed to be the oldest; Sanghyang Nandir, a version danced by males, which is usually thought to precede the female version on the grounds that most dances were supposed to be performed by males; and the female Lègong which Moerdowo attributed to a dance-master requesting the king of Gianyar's permission to choreograph a new version beginning in about 1882 (1977: 92-93).

The use of history to elucidate dance in Bali tells us more about the preoccupations of the authors than what might, or might not, have happened. Java looms large. Not only is it the source of much of what happens in Bali until the 19th century, but the older texts cited are Javanese (as indeed were scholars like Soedarsono and Moerdowo). Now the relationship between various parts of Java and Bali over a millennium or more has been intricate. It has included invasion, imitation, mutual definition by opposition and more. ${ }^{12}$ In some ways it resembles the relationship between the French and English. How far this entitles scholars to use English sources to explain French culture - or Javanese to explain Balinese - is a moot point.

More pervasive is the problem of Balinese sources themselves. As Bandem and deBoer cautiously noted, accounts like the Babad Blahbatuh recount 'history from the point of view of the family, emphasizing its exploits, and tracing its lineage' (1995: 47). In today's terms, they are less 'objective history' (whatever that would look like) and closer to massive corporate public relations' exercises. Babad began to be written only in the 19 th century. ${ }^{13}$ In other words, the texts postdate by 200 300 years the putative arrival of Topeng from Java, in a society which relied

\footnotetext{
${ }^{11}$ Similarly the earliest known reference to the dance-opera form, Arja, which remains popular, is to 1825 (Dibia and Ballinger 2004: 84). However this was probably a variation on classical Gambuh theatre, Arja in something resembling its present form, but with an all-male cast, is recorded as first emerging in 1915. Women, who now play all the lead refined roles, only started dancing in the 1920s, according to Moerdowo, who seemingly relied on oral testimony of actors from Blahbatuh. I Wayan Dibia (personal communication) agrees to the date for the emergence of modern Arja.

${ }^{12}$ Evidently this relationship included adapting and using literary works and cultural practices. However the presence of, say, a Javanese text in Bali is grounds to assume neither that it was constitutive, nor that is explanatory, of cultural practices like theatre or dance.

${ }^{13}$ Indeed, current scholarship suggests the majority were actually written after colonization (Vickers, personal communication). Dr Nyoman Sedana also informs me that he has evidence that this story is a recent addition to the Babad Dalem Sukawati to whom all authors trace the supposedly original account of Lègong. It would seem high time we rethought for what purposes and for whom such texts were written.
} 
overwhelmingly on oral accounts. Whatever was going on seems not to have been a simple linear development. Nor do we have a clear idea of the intended audiences or the circumstances of use. And what of the conditions under which such family chronicles were written? The range of palatable options available to the scribes of such histories would have been very limited in a period when oral accounts suggested princes could impose summary execution for minor displeasures. ${ }^{14}$

We are dealing with what the Oxford philosopher Collingwood called as 'scissors-and-paste' history, ${ }^{15}$ which extracts 'facts' from sources without questioning the circumstances or purpose of their production. This problem bedevilled Moerdowo, who relied heavily on 'well-informed informants' from one village, Blahbatuh. In short, we have Blahbatuh's history of Balinese theatre and dance which, to judge from Balinese use of similar narratives, was designed to preempt and marginalize rival accounts. Indeed the history of scholarship on Bali, like the emergence of performing arts' academies, is inextricably tied up in the intense competition which runs through so much of Balinese society. So, while it would be relatively simple to string together references from the patchy sources on precolonial performance either to support or to refute my argument, both would be equally vacuous and miss the point of why the histories were being written.

The history of Lègong is particularly revealing. The attribution of Sanghyang Lègong to the prince who resided where it was performed is a conventional hagiographic narrative device. Also, imagine the likely fates of choreographers who were rash enough not carefully first to ensure the prince's patronage or to attribute creative genius to their lords and masters. La Danse c'est Moi. From the temple priest's account, we gain a sense of just how contested almost any historical claim is in Bali. His counter-history rejects the mythology of Majapahit and seemingly the grand narratives of aristocracy and even Hinduism. If Moerdowo's dates are remotely accurate, then the reported enthusiasm for this wonderful new dance took over half a century to crank up and then promptly flopped as it was already on its last legs when Europeans arrived in the early 20th century. Significantly, this places the emergence of Lègong as we know it in the dying days of the old pre-colonial order, when North Bali was already colonized and foreigners -Javanese, Arabs and Westerners - had for some time become a palpable presence. Far from being the sublime expression of Balinese classicism, it suggests Lègong was born out of transition. Indeed the unique status attributed to Lègong may in significant measure be a result of the excitement it aroused among Western visitors. ${ }^{16}$

\footnotetext{
${ }^{14}$ My primary sources here are accounts from 1971 by several elderly Balinese in Gianyar who were young adults under the rajas. As their testimony substantiates recent scholarship (e.g. Wiener 1995; Vickers 2005) which has questioned romantic interpretations of Balinese kingship (e.g. Geertz 1983), prima facie they should be taken seriously.

${ }^{15}$ Collingwood 1946: 257-66. To Collingwood, scissors-and-paste was opposed to historical and cultural understanding, which involves a dialogue between scholarly analysis and appreciating events as the participants themselves did.

${ }^{16}$ Stephen Davies, who for many years has conducted research on the history of Lègong, considers the date of the late 1880s likely its inception. However his various sources place its modern form, which includes crucially the role of the Condong, as probably dating from the late 1920s (personal
} 
Retrojection, anachronism, partisan claims, plain invention and simple muddle are the hallmarks of the written history of Balinese dance. Such exercises in naïve realism are quite distinct from the critical interrogation we need and which requires both an understanding of the lived worlds of Balinese at the time and equally of the background, motives and interests of their subsequent commentators. Indeed realist history of the kind discussed starts to appear as a distracting search for elusive origins and imagined essences, which conflates PR with understanding of the past. More important, I think, than guesswork and fantasy about Bali's dance past is the systematic way in which all these accounts make Balinese the acquiescent subjects of forces beyond their control or even understanding. Transcendental agents History, Java, Feudalism, Religion - dictate what these passive native dance minds and bodies do. As in the captivating image of the little Sanghyang dancers possessed by Divinity, Balinese have been elegantly usurped from mastery of their own theatre and dance.

\section{How dance got into Balinese theatre}

There is no single story as to how Bali became identified with dance as an international brand. Here I have space for only two strands. The first, as Michel Picard has shown, is how cultural tourism demanded a new kind of performance. Beginning in the 1920s, the Dutch organised weekly dances to attract visitors at a growing number of hotels in Denpasar. Existing Balinese theatre was unsuitable for many reasons. It lasted all night; it was extemporised to adjust to audiences' reactions; the singing was strange to western ears; the lengthy dialogue was in Balinese; and westerners were unfamiliar with the stories. The answer was radically to re-imagine theatre as dance.

The problem of duration was resolved in the same way as at the Bali Hotel - that is, by the juxtaposition of short dances and, in the case of dance theatre, by the reduction of a dramatic genre to an accelerated series of the most spectacular episodes (Picard 1996: 141).

After the Paris Exhibition of 1889, Central Javanese music and dance had been hailed in Europe as high art. However

unlike Javanese dances, appreciated by European connoisseurs since the end of the last century, Balinese dances acquired the prestige that they have today only after becoming tourist attractions (Picard 1996: 135).

So most of what we know as dance in Bali emerged to meet foreign tastes.

To satisfy this demand, dance had to be radically re-imagined. What is at issue is nicely encapsulated in the Indonesian name given to this genre, tari lepas, 'free

communication). This would place the emergence of Lègong as we know it precisely at the time tourism was really developing. 
dance', that is dance detached from all the contexts of its cultural performance, then branded and franchised as uniquely and authentically Balinese. It is in this sense that I use dance in what follows, as opposed to theatre, which I take to be the kinds of dramatic stories Balinese performed for themselves. This leaves what Europeans, and now sometimes Balinese, understand by dance appropriately problematic. ${ }^{17}$

Decontextualizing took several forms. Baris, Topèng, Jauk and Tèlèk were extrapolated from theatre and religious rites. Other dances, such as Panyembrama and Olèg Tamulilingan were choreographed for western audiences, the latter at the request of an English impresario (Coast 2004: 105ff.). Some, like Lègong, were so stripped down that it is difficult to know quite what relationship they bore to their precursors.

The Balinese were far from passively compliant in the creation of dance. From their first encounter with the Dutch, Balinese rulers had been preoccupied with how to deal with these alien beings. Conquest shattered the Balinese vision of the world and left them urgently seeking a suitable medium through which to relate to the new rulers with their mysterious wishes. Put this way, kebyar becomes partly a complex act at cultural translation. In 1971 the late Cokorda Gedé Agung Sukawati gave me his account, which contained fascinating glimpses of how Balinese purposefully set about determining Dutch predilections. Living opposite the Hotel Bali in Denpasar and through becoming a guide, the Cokorda inferred what Europeans wanted was art. Realizing that Balinese could neither yet appreciate nor deliver what the colonial masters wanted, the family decided to lure to Ubud the only foreigner they knew who seemed to have the right qualifications, the then bandmaster to the Sultan of Yogyakarta, a certain Walter Spies. The outcome was a celebrated chapter in the history of the romanticisation of the island.

By the late 1990s, Bali had grown into a multi-billion dollar tourist industry. How is dance implicated in all this? On the one hand, dance is constitutive of Bali as a brand in a highly competitive market. As the island is increasingly built over with unplanned industrial development, what distinguishes it from its Asian competitors if not its artistic culture (seni budaya), exemplified by its most accessible form, dance? On the other hand, dance has become a major industry. No one is sure, but tourist dances probably account for well over ninety percent of performances, except perhaps on a few festival days. The musicians and dancers are shipped not in buses, but packed together in the back of trucks that are used otherwise to transport cattle and merchandise. Balinese dance epitomises the brute commoditisation of labour. Fels's vision of dance as 'poetry, movement created by the soul, possessed and conquered' now has a darker sense.

The commoditisation of dance in Bali adds a twist to Adorno and Horkheimer's analysis of the culture industry (1993) in that it is not, as in America, one among

\footnotetext{
${ }^{17}$ There was almost certainly much local variation within Bali. And the dichotomy between 'authentic' and tourist performances was complicated by becoming part of the singular dialogue or heteroglossia that is contemporary Bali.
} 
many industries, which happens to specialise in the production of new cultural forms for mass markets. In Bali the sale of 'culture' now comprises many of the island's major industries and has come to constitute what Bali itself is. The industrial tail now wags the cultural dog.

Under these circumstances an interesting tension emerges between the demands of industry for the mechanical reproduction of dance and the élite national arts' academies, which claim a European-style conservatoire model of excellence. If the economic impact of the culture industry is fairly obvious, the political implications have gone less noticed. As Benjamin wrote

For the first time in world history, mechanical reproduction emancipates the work of art from its parasitical dependence on ritual... But the instant the criterion of authenticity ceases to be applicable to artistic production, the total function of art is reversed. Instead of being based on ritual, it begins to be based on another practice - politics (2005: IV).

Politics has come to permeate performance. After all, what is more political than the bland naturalisation of feudalism? And a hallmark of the New Order was a genre, borrowed from Java, and endless reproduced. In Séndratari, a spectacular mass dance ballet, the dancers silently mime to the dialogue of a single dalang (or puppeteer, Hough 1992), ${ }^{18}$ in a (presumably unintended) caricature of the political order itself.

Bali's increasing dependence on its industrialised culture is reflected in its new commercial mass media. BaliTV, launched as the medium of Bali's cultural arts, for nineteen hours each day reproduces for Balinese an imaginary island of endless beautiful dances and ceremonies, which is even more insidiously political. Commercialisation has come full circle because it is widely rumoured that, instead of receiving fees, dance troupes pay for the privilege of performing on TV, which is now unashamedly advertising, straight-faced, under the banner Pulau Dewata - the Island of the Gods.

\section{Bali as difference}

Another way that Bali became linked with dance was through the colonial exhibitions. Most spectacularly the Paris Colonial Exposition of 1931 brought Bali to Europe and to the attention of European intellectuals at a crucial moment. The Dutch constructed a special East Indies Pavilion, the highlight of which was dances by a full Balinese troupe. It was an unequal encounter. One of the musicians, Anak Agung Gedé Ngurah Mandera, remarked afterwards: 'We were hidden away, we Balinese, like serfs, and we saw little of Paris or foreigners' (Coast 2004: 42). In a sense the European visitors to the Exposition saw equally little of Bali and its theatre. As the quotations earlier make clear, as with contemporary tourism, what they saw had been largely pre-articulated for them along familiar Orientalist lines.

\footnotetext{
${ }^{18}$ Suharto (or his wife) was often dubbed the 'dalang' behind New Order machinations.
} 
Within the broader scheme of things, Bali was significant insofar as it was different in ways that fitted European needs. That Balinese theatre occupies an important niche in the theoretical world of performance, through the work of Artaud, is not accidental. As Savarese put it:

Artaud was not in fact interested in Balinese culture; he used the Balinese performance because its extraneousness to his own culture made it possible for him to delineate a difference. Artaud, finally, did not want to increase knowledge about Balinese dance but to use it to create a short-circuit... Artaud's vision distorted the meaning of a tradition and a culture of which he was essentially ignorant: the Balinese performances represented something very different from what they actually were, but something nevertheless necessary for him (2001: 71). ${ }^{19}$

Ironically, Bali's greatest asset, whether to artists, scholars or tourists, was not what it was, but what it was not - its difference.

\section{Digression - the ultimate happy island}

From a musician's viewpoint Bali is the ultimate happy island where music, dance, and drama are not only loved by all but play a most important part in daily life. In ceremonies of the temple and the village music is as necessary as incense, flowers, and offerings (McPhee 1966: 3)

Bali is not just different. It is the luminous acme of human difference, which at once sheds light on the baleful condition of modern society and offers relief from it, through myth and counter-myth. ${ }^{20}$

Bali has long been famous as an earthly paradise in which a favoured race of men live in Utopian harmony with their own kind, with nature and their gods...[But] Bali is neither a last nor a lost paradise, but the home of a peculiarly gifted people of mixed race, endowed with a great sense of humour and a great sense of style... Something in the atmosphere, which is extraordinarily clear and light, seems to have turned all the processes of man's thought into beauty.... They have fashioned Bali out of its original jungle into this incomparable harmony of rice-fields, temples, villages, so different each from the other, yet so characteristically Balinese (de Zoete and Spies 1938: 2-3).

This romanticising, in which Spies played so important a part, soon turned to Balinese bodies and dance. ${ }^{21}$

\footnotetext{
${ }^{19}$ We necessarily represent something as something else (Goodman, Languages of art). At issue are the kinds and purposes of representation.

${ }^{20}$ If, as Baudrillard argued, the basic commodity that underpins consumer society is not a positivity (a particular good or service), but signs promising access to difference (1970; 1988: 125), then Bali, epitomised by Balinese dance in its exquisite, timeless, ritual, arcane Otherness, was beautifully designed to fit tourists' and aesthetes' predilections.
} 
their movement, even more than their physical beauty, is the first thing that strikes one about Balinese people... Wherever he may be ...squatting naked on a rock in the river in the act of making offerings to the stream, the Balinese is so perfectly in harmony with his surroundings and so graceful in his poise that we almost have the impression of a dance...Certainly the Balinese child has from infancy its limbs trained and persuaded to become perfectly pliant (de Zoete and Spies 1938: 5)

Balinese embody a unique and unproblematic synthesis of unspoilt naturalness and exquisite discipline.

Little girls who appear like small golden idols in the Legong dance, and render with astonishing refinement and skill its complicated evolutions, will a moment before have been sitting half-naked on the ground de-lousing each other (de Zoete and Spies 1938: 5).

Had the de-lousing and dancing been presented in reverse order, would the effect have been quite the same?

The European contradictions between the discipline necessary for civilization and the ambiguous nostalgia for the freedom of nature are neatly sutured in dance. For

dancing is to them something quite different, another mode of being... It is natural that such a genius for movement as that of the Balinese should find expression in the art of which movement is the only body - in music. Music permeates their life to a degree which we can hardly imagine; a music of incomparable subtlety and intricacy, yet as simple as breathing...dancing accompanies every stage of a man's life from infancy to the grave (de Zoete and Spies 1938: 6-7)

To paraphrase Voltaire, if dance did not exist in Bali, it would have been necessary to invent it (cf. Tilley 1997). In effect Europeans did.

Romanticising Bali as about dance has however another face, about which Westerners suddenly become evasive. An American visitor in the1930s observed of tourist performance in Denpasar that the hotel which had put on tourist dances

has also attempted to inject as much sex as possible into the dances, and sex is the one quality that is almost entirely absent from the Balinese dance, therefore its appearance strikes a false note (Picard 1996: 141), citing a visiting American librarian, Philip Hanson Hiss 1941).

According to whom is it absent?

${ }^{21}$ Hitchcock \& Norris (1995: 4-5) note in passing the impact on Spies of the artistic movement in Hellerau, a theme that Mike Hitchcock thinks may be crucial in pre-articulating Spies's vision of Bali (personal communication). 
Hiss's complaint certainly squares with that large camp of visitors who wish to spiritualise (and infantilise?) Balinese. ${ }^{22}$ However to others it strikes a false puritan note, antithetical to what more sophisticated Europeans and North Americans found distinctive about Bali, as 'there is a perfect simplicity in the attitude of the Balinese towards sex' (de Zoete and Spies 1938: 3). On what authority, as what kind of knowing subjects, do they speak? Certainly Spies was not an uninvolved observer, but a participant. His imprisonment by the Dutch government on charges of homosexuality has often resulted in him being portrayed as the heroic victim of jealous Dutch petty Calvinist attacks (e.g. Aldrich 2003: 161-5). What is neatly omitted here is that the concern over both Walter Spies and the noted Canadian musicologist, Colin McPhee, was not with their homosexuality, but their reputations for paedophilia, which forced McPhee to flee Bali. That these two were the pivotal figures in articulating the emergence of Balinese arts through painting and dance, and music respectively, raises intriguing questions.

Dance is never long off stage however. Adrian Vickers notes McPhee's involvement with I Sampih, 'the wild and talented child dancer' whom he nurtured into becoming a star and who emerged as 'the apotheosis of the fetishisation of Balinese boys' (Vickers n.d.: 27)

Dance and Westerners' imaginings about Balinese dance, dancers' bodies and Balinese sexuality are intricately intertwined with colonial power.

In the ethnography of Bali there are passing references...to a 'normality' of sexual freedom in Bali. Building on the trope of the East as a place of sexual freedom, the expatriates seem to have created a life style in which bi-sexuality was common (for example with Belo [McPhee's wife at the time] and McPhee, as well as at least some of their American friends), as was sex with Balinese servants, even those adopted into one's family. But this sexual freedom of the westerners was constructed as sexual freedom of Balinese (Vickers n.d.: 22, parentheses in the original)

That several of the Balinese who were close to these Westerners went on to be leading figures in the anti-colonial Independence movement suggests quite how incommensurate expatriate and Balinese understandings were - and, for the most part, remain.

The subjectivities formed by the Balinese interactions with foreigners, sexual, artistic or otherwise, were formed on strongly unequal terms, in a pathological social context. But out of this relationship Balinese were forming their own ideas of the 'modern'.... That those most closely in contact with westerners should fight

\footnotetext{
${ }^{22}$ A famous example is Nehru's reported description of the island on a state visit in 1950 as 'the morning of the world'.

${ }^{23}$ Apart from his portrayals of Balinese bodies, dancers and other, Spies's involvement in the emergence of the Kècak dance is part of received history. This account however replicates the stereotype of passive Balinese. And I have been given quite different accounts by Balinese. I Sampih was later a leading dancer in John Coast's British and American tour, only to be murdered on his return. Not coincidentally, the stars of the tour were pre-pubescent girls.
} 
to the death for independence highlights a number of complexities: Balinese resistance to Westerners is written over in favour of an eroticised welcome in texts such as McPhee's (Vickers n.d.: 31)

The risk in exposing the narcissistic power behind Western articulations of Balinese and their dance, recursively, is of sanctifying the Balinese. The Dutch doctor, Julius Jacobs, suggested another face when he wrote about how one king 'offered him a dancing girl as company for the night and recounted how some of the court dancers were in fact prostitutes, whose livings supported the rajas' (Vickers 1989: 87). In the Pañji cycle, the image of the artistic prince, at once dancer, connoisseur of dance and lover of beautiful women stood in a complex relation to its instantiation, when the rapturous textual depiction of romantic seduction to a Western audience 'translates into rape' (Vickers 2005:190). The scope for collusion between the old and new élite in how they chose to imagine dancers is great. Perhaps we should ask: at any historical moment, what were the choices that, realistically, dancers had, or that women especially had to become dancers? ${ }^{24}$

So what about the beautiful dancers, epitomised by the little Lègongs? During fieldwork elderly women would recount to me how their parents fearing the attention of rapacious aristocrats, sometimes used pre-emptively to scarify the most beautiful. The implicit assumption that the notoriously randy princes, whose demonstrable will over their subjects was a significant measure of their power, actually treated the pre-pubescent Lègongs as sexually untouchable. ${ }^{25}$ I cannot resist the vision of a horny prince, bursting with uncontrollable libidinous urges, carefully checking first with the young lady in question whether she has in fact menstruated and then withdrawing infinitely apologetically like the - almost entirely fictitious perfect English gentleman on discovering he has made a terrible mistake. Misapprehensions about the exercise of power - whether over people or representations - are not the only problem. There are also problems of cultural translation.

\section{Problems of cultural translation}

In Balinese conventionally there was no word for art, nor was there a word for dance. ${ }^{26}$ Balinese generally referred to theatre, shadow plays and non-narrative

\footnotetext{
${ }^{24}$ Such accounts, far from being unique to Bali, appear to have been not-uncommon in South East Asia. Creese has explored how such practices were underwritten in Bali by literary depictions of women's sexuality (2004).

${ }^{25}$ Coast (2004: 33) recorded how the military commander of Bali abducted a fifteen year old dancer with the connivance of two rajas as late as the 1950s. de Zoete and Spies note that

The dancing life of a legong (except as a teacher) ends with her marriage, which will normally take place at thirteen or fourteen; for legongs are much in the public eye, and much sought after, and often marry into a high caste (1938: 229).

This happy little account makes assumptions about the age of menstruation and what Balinese knew about their ages.

${ }^{26}$ Terms for training, judging and commenting on dance and theatre remain primarily technical and aids to performance. The vocabulary of aesthetics has had to be borrowed from Europe and is
} 
dance simply as sesolahan or igelan (in high and low Balinese respectively), and acting, singing, dancing or acting as a puppeteer as masolah or ngigel, perhaps best glossed as 'performance' and 'performing'. Tempting as it is to dismiss the confusion as trivial, misunderstandings not only continue to thrive, they bear on the asymmetrical relations of power that Westerners have long exerted over Balinese and are loath to relinquish (Hobart 1990).

Among the problems - here assuming Balinese and 'western' ideas of dance (the latter itself deeply contested) to be commensurate - two are immediately relevant. First there remains the curiously colonial-looking presupposition that western categories of analysis are ontologically unchallengeable and ipso facto epistemologically sufficient to describe and comment on the entire congeries of practices of a society with a quite different philosophical and cultural history.

Further, most accounts assume an unproblematic transparency between the object of inquiry and the frame of reference. There is an unremarked circularity in representing Balinese practice as dance tout court. If nothing else, out of good intellectual manners, we should first ask how Balinese have articulated their own dramatic practices, indeed whether they constituted a distinct category. Quite simply, it is tautological and essentialist to represent dance simply as dance. ${ }^{27}$ The question is what have people represented as dance - and, more important, represented dance as - under different circumstances and to whom? For Bali, a plethora of possibilities present themselves. Among the most obvious are theatre/dance as a religious offering required to complete rites; as the practice of disciplined self-transformation; as exemplifying techniques of mastery over body and mind; theatre as social commentary and criticism; and more recently Balinese 'dance' as a brand label, a means of livelihood or a way out of poverty. The presumption that we know what dance is and how to translate it is old fashioned Eurocentrism refried.

As this discussion has been theoretical, let us consider how it might bear on the important question of appreciating the body in dance. The fact that dancers universally have bodies makes the step of projecting culturally specific western model onto Balinese alluring. ${ }^{28}$ Balinese however imagine bodies differently according to several possible schemes. One popular model indicates the degree of disjuncture. On this account Balinese bodies are labile. They are capable of reshaping themselves through will, but can easily be entered (karangsukang, 'trance') or disintegrate into constituent parts. So mastery, or command, over the body is important. This is quite different from the mechanical metaphor of control, widely used in Europe to discipline bodies. By contrast Balinese, on this account, imagine different body parts as having different proclivities, which the disciplined

supplementary, comprising dollops of the ethnic gloss and cultural marketing that westerners demand - and duly receive, for a price - of the authentic Balinese dance experience.

27 See Goodman 1968. As accounts suggest pre-colonial theatre lasted for days, even the idea of a discreet performative space and time is questionable.

${ }^{28}$ I take it that universalist and naturalist accounts are cultural. Even were they not, such schemes would be little use in explaining what makes Balinese dance different. 
human must weave into an elegant working whole. Similarly pre-conquest polities depended on the ruler managing to command the agreement of other lords and ordinary subjects to pursue a common venture. ${ }^{29}$ Bodies and the world are not separate but affect one another. So dance, in instantiating momentary mastery, helps order the world; while material process always brings the threat of disrupture. In practice a lifetime of work (through manusayadnya, life cycle rites), discipline and care are needed to develop a mature being. The distinctive grace and poise of trained Balinese bodies is not achieved casually.

\section{An alternative account}

By way of social background, it is useful to appreciate that, behind the appearance of luxury in the tourist sector, much of the capital is foreign and Bali shares many of the problems of the rest of Indonesia. Parts of the island remain desperately poor. During his voyages in the 1850s, Alfred Russell Wallace remarked on the abject poverty and misery of ordinary Balinese in contrast to the wealth and comfort of the rulers. The economics and politics of pre-conquest Bali run counter to fantasies of an island where dance and music were popular pastimes. The image of traditional Balinese villages as full of beautiful young dancing maidens and throbbing gamelans is anachronistic. Until the second half of the twentieth-century, most villagers could barely afford everyday clothes, far less the gilded ornamental costumes and expensive gamelan, which were owned mostly by the courts and by some richer village groups. ${ }^{30}$ Bali is not alone in having depended heavily on patronage for the arts.

A long period of centralised rule ended in 1651 and Bali was thrown into a hundred and fifty years of internecine struggle between rival warlords. Many were low caste upstarts who butchered or connived their way to power. The theatrical celebration of an unchanging world-order, founded upon noble aristocratic values, in which kings were mostly heroic, wise and just, and their subjects loyal, devoted and happy is starkly juxtaposed to the terror of sudden death, enslavement, rape, pillage, and poverty that was most people's lot. ${ }^{31}$ It was probably close to a condition with

no arts; no letters; no society; and which is worst of all, continual fear and danger of violent death; and the life of man, solitary, poor, nasty, brutish, and short (Hobbes 1914: 65).

\footnotetext{
${ }^{29}$ Philosophically this account draws, among other things, upon Balinese rescensions of Sämkhya, in which material process is tripartite, comprising passion, desire (rajas), benightedness, ignorance, lust (tamas), purity, thought (sattwa). Significantly a more Indian translational manual fits quite well and is illuminating: spontaneous activity (rajas), rational ordering (sattwa) and objectification or inertia (tamas) (cf. Larson 1987).

${ }^{30}$ That gamelan and costumes might have been loaned to client villagers for practice does not transform the relations of power.

${ }^{31}$ Vickers (2005) offers a fascinating analysis of how Balinese articulated this period through the idealised figure of the desiring, bellicose and artistic prince.
} 
However in Bali arts and letters articulated a vision of society that stood in such magnificent contrast to, and denial of, what was actually going on.

Bearing in mind the difficulties of determining quite what the names of genres referred to, let me offer a suggestive sketch of the development of theatre and dance, which is simply designed to stimulate discussion.

$>$ In the late seventeenth century, any remaining semblance of stable government collapsed, life became anarchic. Balinese developed Gambuh and Wayang Wong celebrating a noble ordered world.

$>$ In the latter part of the nineteenth century, upstart rulers claimed fabulous genealogies (babad), while masked Topèng subsequently legitimised such rampant status-climbing.

$>$ With the collapse of royal power, after 1915 popular dance-opera Arja promptly began to flourish, which celebrating the lives of ordinary Balinese.

$>$ Simultaneously a spectacular new musical and dance style, Kebyar, sprang up in precisely the village in North Bali, Jagaraga, where the Dutch had first set foot to conquer Bali. ${ }^{32}$

$>$ After 1910, as the Dutch established their administration and tourism gradually began in earnest, Balinese suddenly (re)discovered dance. Lègong, seemingly moribund, was created in a recognizable form, and Jangèr was created.

> In 1942, as Dutch colonial rule collapsed before the Japanese invasion, crossdressing dance, bebancihan, which has since become a major genre in its own right, suddenly came into vogue. ${ }^{33}$

In 1965, following a supposed communist coup and the execution of some 100,000 people in Bali alone, Derama Gong, spoken theatre in ordinary Balinese, burst into fashion.

How are we to relate such an alternative genealogy to the received accounts of dance?

\section{Some confusions - creativity}

The meetings between Westerners and Balinese frequently involved misunderstandings, which rested on unrecognised differences in cultural

\footnotetext{
${ }^{32}$ The timing of quite new forms of theatre and dance - modern Arja in 1915 and almost simultaneously Kebyar in North Bali - does raise fascinating questions as to whether the old political order, far from fostering the performing arts, might not have inhibited them. Theatre in Bali has long been a privileged, if risky, forum for social and political commentary. It might be that we shall have to rethink the role of the Balinese rajas as patrons of the arts.

${ }^{33}$ These included Mergapati, Demang Miring, Candra Metu Panji Semirang. According to Moerdowo, it was the conquering Japanese commander in Bali who 'summoned I Nyoman Kaler a famous dancer in Denpasar to create new dances for entertainment purposes, and so the solo dances were created (1977: 108). It would seem that, in significant part, bebancihan emerged out of an engagement of Balinese with Japanese military needs or imaginings at the time. At each turn, the history of Balinese dance grows curiouser and curiouser.
} 
presuppositions. ${ }^{34}$ One of the most celebrated is about theatre. Clifford Geertz famously depicted Balinese kingship as

a theatre state in which the kings and princes were the impresarios, the priests the directors, and the peasants the supporting cast, stage crew, and audience (Geertz 1980: 13).

An entire category of South East Asian polity rests on an image of theatre, which Geertz imported from Europe without ever inquiring what Balinese conceptions might be - so leaving them constituting their politics through a model of which they had no inkling. Remarkably, almost no one has even commented on it.

Similar presuppositions bedevil discussion of creativity in Balinese dance. Europeans and Americans presuppose evolution and progress to be good. So, ideally artistic and cultural production is innovative. There are no grounds however for imposing these ideas upon other peoples, who may imagine artistic excellence otherwise. For example, it could be that a previous order - from which the present day has fallen away - may be the ideal. Then creativity would involve re-imagining the past differently or more perfectly. Much Balinese creativity arguably consists in elaborating, rather than going beyond the received framework. This proclivity is underwritten by Balinese social structure which, certainly until the recent past, largely comprised corporate groups. Such groups are exceptionally efficient at organizing activities, but tend to be conservative and to inhibit deviation from the expected. ${ }^{35}$ If one Balinese opens a successful art shop, cafe or dance group, soon after fifty similar ones will spring up.

There is however a more interesting sense of creativity, linked to crisis. When the existing order breaks down irreparably, it would seem that Balinese are driven furiously to articulate some new order, as the links between social disruption and theatrical innovation above suggested. ${ }^{36}$ Further confusion arises when Europeans and Americans insist on identifying the creative genius behind a dance or composition, because for them the knowing and creative subject should be identifiable with an individual. Balinese, by contrast, tend to stress the degree to which a finished composition or choreography is inevitably the work of a complex agent, ${ }^{37}$ which may be one reason Westerners' hagiography of Balinese star dancers

\footnotetext{
${ }^{34}$ This critical study of absolute presuppositions Collingwood argued to be the study of metaphysics proper (1940). A serious study of Balinese theatre should perhaps start with how Balinese judge performance. For example, actor-dancers listen to the angkiang, literally 'the breath' of the music and, conversely, musicians work to the angkiang of the dance. The dialogic quality also emerges in how dancers talk of the necessary condition for extemporizing, saling enyuhin, to make a path for your fellow actors, without which performance dies on stage. The most fascinating is taksu, what makes a particular performance come to life, what makes an audience forget they are watching theatre and become absorbed, what imbues an actor with something special.

${ }^{35}$ So another aspect of Balinese engagement with foreigners might have been the opportunity to explore possibilities relatively closed to them within their own society.

${ }^{36}$ Perhaps we should speak of the state between crises as 'normal arts', by parallel with Kuhn's depiction of the periods between scientific revolutions as 'normal science' (1970).

${ }^{37}$ On complex agency, see Inden 1990.
} 
often ends disastrously. Cross-cultural studies of performance need to engage not just in critical history but also with different, potentially incommensurable, cultural presuppositions without sliding back into Eurocentrism.

It would be inappropriate to approach the singular history of fashions, misunderstandings and closures which surround Balinese dance and theatre solely in terms of the preconceptions foreigners have had. Balinese are arguably equally caught up, not only in their own presuppositions, but also in coming to terms with those imposed upon them. This is not the place for a detailed exposition. So I confine myself to two examples.

A feature of most Balinese theatre and dance is its apparent absorption in an imaginary pre-colonial past. Evidently the reasons are complex. However, perhaps we should consider, in the late 20th and 21 st centuries, what is involved in the stark contrast between the endlessly repeated depictions of a glorious feudal past when, by most independent accounts, it was a time of peculiar savagery and misery for the vast majority of the populace. However skilfully actors may draw upon textual ideals as a contrast with, and judgement upon, contemporary Indonesian political abuse and corruption, so doing disguises the uncomfortable degree of continuity between the past and present. ${ }^{38}$ For a people who have been catapulted in some twenty years (between about 1975-1995) from peasant farming to servicing the demands of international mass tourism, some nostalgia is understandable. Whether studiously ignoring the social issues raised by modernization -be they rocketing land prices, hidden poverty, environmental degradation, money laundering, drug dealing or sex tourism - is the best way of addressing the multitude of problems contemporary Bali faces is another question.

A striking aspect of modern Bali is ritual and artistic inflation. While royal cremation rites seem to grow ever larger, something similar is happening with dance. The explosion of supposedly original kebyar dances is now locked into ever more magnificent portrayals of royal opulence, the rigid codes of which lead to wonderful absurdities. Gold crowns and gilded vestments may look fine on princes and princesses (even if quite fanciful). But quite what is up when padi finches, fisherman off to sea and farmers working muddy rice fields are decked out in gold? For all the talk of creativity, not least by Balinese themselves, you could equally argue that Bali is in the throes of acute artistic involution. ${ }^{39}$ An example is the annual Bali Arts Festival, which began as an inspired occasion for Balinese to appreciate their own arts and performing arts. Now it consists mostly of minor variations or straight repetition of genres which date back between thirty and ninety

\footnotetext{
${ }^{38}$ Under the New Order, actors I know who attempted to address modern themes, were threatened with grave sanctions. Recycling a domesticated and sanitized past through pageants, competitions and arts' festivals suited the regime well.

${ }^{39}$ While Kebyar might suffer from involution, is it really more insular and inward-looking than the closed worlds of western ballet and contemporary dance?
} 
years, a trend disguised in part by the sheer virtuosity which Balinese so often bring to performance. ${ }^{40}$

So is Bali a fine instance of multiculturalism, where inter-cultural contact however glorious or seedy its genealogy - has allowed a unique flourishing of Asian performing arts? Or is this how local dance markets itself as global, and a model for other parts of the Malay world? Or are we witnessing a shining moment - Kebyar after all is, literally, a brilliant, but inevitably brief, light - the outcome of singular circumstances, which is slowly fading under irresistible commercial and institutional pressures? ${ }^{41}$ By almost any account, dance has become quite inextricably embroiled in the over-heated imaginings of outsiders and, in rather different ways, of Balinese themselves. The result has often proven less a beautiful love affair than a sticky mess. Critical rethinking is not a luxury, but a necessity for anyone who wishes seriously to appreciate Balinese theatre and dance in its complexity. What I have tried to do here is to evaporate some of the damp dreams, so that Balinese dancers, choreographers and scholars have greater freedom to rethink their own heritage and what they want to do next.

\footnotetext{
${ }^{40}$ In private, several leading figures of the arts' world have expressed their serious concern to me, but are themselves largely trapped by processes beyond their control. One problem that several distinguished choreographers and composers highlighted was the deep conservatism of Balinese audiences, who they felt were uninterested in exploring the new and just wanted more of the same. The intensity and constructiveness of discussion generated when this piece was presented to senior Balinese thinkers, performers and also academics from the Institute of Arts in July 2006 suggests the arguments resonated with its immediate subjects.

${ }^{41}$ What might have contributed to this flowering, if indeed it was, is inevitably disputable. I would certainly include a loosening of feudal power, remarkable personal physical and group discipline, a tradition which valued technical mastery and the rare opportunities opened up to a mostly very poor people to better themselves through performance. Those Balinese who make a living through performing in the tourist sector and on the international circuit have neatly turned others' projections onto them of exoticism and difference into a way of providing themselves and their families with a living.
} 


\section{References}

Adorno, T. \& Horkheimer, M. 1993. The culture industry: enlightenment as mass deception. In The cultural studies reader. ed. S. During, London: Routledge.

Aldrich, R. 2003. Colonialism and homosexuality. London: Routledge.

Bandem, I Madé and deBoer, F.E. 1995. Balinese dance in transition. Kuala Lumpur: Oxford University Press, (1 ${ }^{\text {st }}$. Edition 1981).

Baudrillard, J. 1970. La société de consommation. Paris: Gallimard, 1970.

Baudrillard, J. 1988b. Symbolic exchange and death. In Jean Baudrillard: selected writings. ed. M. Poster, trans. C. Levin, Oxford: Polity.

Benjamin, W. 1969. The Work of Art in the Age of Mechanical Reproduction. In Illuminations. ed. H. Arendt, New York: Schocken, 1969; accessed online on $15^{\text {th }}$. February 2006 at $<\underline{\text { http://www.marxists.org/reference/subject/philosophy/works }}$ /ge/benjamin.htm $>$ transcribed by A. Blunder, corrected Feb. 2005.

Boon, J.A. 1977. The anthropological romance of Bali. Cambridge: University Press.

Clifford, J. 1988. On ethnographic authority. in The predicament of culture. London: Harvard University Press.

Coast, J. 2004. Dancing out of Bali. Singapore: Periplus.

Collingwood, R. 1940. An essay on metaphysics. Oxford: Clarendon Press.

Collingwood, R. 1946. The idea of history. Oxford: Clarendon Press.

Creese, H. 2004. Women of the Kakawin world: marriage and sexuality in the Indic courts of Java and Bali. London: Sharpe.

Dibia, I Wayan and Ballinger, R. 2004. Balinese dance, drama and music: a guide to the performing arts of Bali. Periplus: Singapore.

Fels, F. 1931. À l' exposition coloniale: danses de Bali. Vu journal de la semaine, 173, 8, July 995.

Fox, R. 2002. From text to television: mediating religion in contemporary Bali. Unpublished $\mathrm{PhD}$ thesis in the University of London.

Geertz, C. 1980. Negara: the theatre state in nineteenth-century Bali. Princeton: University Press.

Goodman, N. 1968. Languages of art. Indianapolis: Bobbs-Merrill.

Hiss, P.H. 1941. Bali. New York: Duell, Sloan and Pearce.

Hitchcock, M. and Norris, L. 1995. Bali, the imaginary museum: the photographs of Walter Spies and Beryl de Zoete. Kuala Lumpur: Oxford University Press.

Hobart, M. 1990. Who do you think you are? the authorised Balinese. In Localizing strategies. ed. R. Fardon, Edinburgh: Scottish Academic Press, 1990, 303-38.

Hobart, M. 2000. Cabbages or kings? Balinese rulers as articulators of worlds. In After culture: anthropology as radical metaphysical critique. Yogyakarta: Duta Wacana Press; available online at: www.criticalia.org, accessed 2 August 2005.

Hobbes, T. 1914. Leviathan. London: Dent. 
Hough, B. 1992. Contemporary Balinese dance spectacles as national ritual. Monash Centre of Southeast Asian Studies, Working Paper 74: 1-35.

Inden, R. 1990. $\quad$ Imagining India. Oxford: Blackwell.

Kuhn, T.S. 1970. The structure of scientific revolutions. 2nd. edn. Chicago: Univ. Press; first edn. 1962.

Larson, G.J. 1987. Introduction to the philosophy of Sāmkhya. In Sāmkhya:a dualist tradition in Indian philosophy. eds. G.J. Larson, \& R.S. Bhattacharya, Princeton, N.J.: Univ. Press.

McPhee, C. $1947 . \quad$ A House in Bali. London: Gollancz.

McPhee, C. 1966. Music in Bali: a study in form and instrumental organization in Balinese orchestral music. London: Yale Univ. Press.

Moerdowo, Raden Mas. 1977. Reflections on Balinese traditional and modern arts. Denpasar: Udayana University.

Picard, M. 1996. Bali: cultural tourism and touristic culture. Singapore: Archipelago Press.

Prunières, H. 1931. Musique et dances Balinais à l'Exposition Coloniale de Paris. Journal de Genève 16 October.

Savarese, N. 2001. Antonin Artaud sees Balinese theatre at the Paris Colonial Exposition. The drama review 45, 3: 51-77.

Soedarsono. 1972. Djawa dan Bali: dua pusat perkembangan drama tari tradisionil di Indonesia. Jogjakarta: Gadjah Mada University Press.

Tilley, C. 1997. Performing culture in the global village. Critique of Anthropology 17, 1: 67-89.

Vickers, A. 1989. Bali: a paradise created. Ringwood, Victoria: Penguin.

Vickers, A. 2005. Journeys of desire. Leiden: KITLV Press.

Vickers, A. n.d. Our colonial children: the boys and girls of Bali. Unpublished paper.

Wiener, M.J. 1995. Visible and invisible realms: power, magic, and colonial conquest in Bali. Chicago: Univ. Press.

de Zoete, B. and Spies, W. 1938. Dance and drama in Bali. London: Faber and Faber. 